\title{
Imagen virtual, imagen real
}

\author{
Dunkerque | Christopher Nolan | 2017 \\ Françoise Moscovitz
}

Le regard qui bat [La mirada que golpea]

Recibido: 21 de diciembre 2017; aceptado 9 de marzo 2018

\begin{abstract}
Resumen
La autora interpreta el malestar y el enojo que sintió al ver la crónica de la operación Dynamo, Dunkerque, a partir del espanto generado a través de la música, los planos insistentes sobre los heridos y los muertos. Un insulto a estos héroes muertos. Este tipo de películas puede tener un carácter pedagógico, pero se trata más bien de gozar de un espectáculo espantoso. El espectador es testigo de una historia del pasado, pero lo deja en una posición pasiva.

La autora analiza también el grado de tolerancia: hay una violencia aceptable y otra que no lo es. Distingue también las producciones que se dirigen a las pulsiones destructivas de aquellas que se ocupan de liberar al espectador. En el caso de esta película, sólo se trata de la inhumanidad de la destrucción ciega. Finalmente, reflexiona sobre la relación del cine con el arte pero también tiene una relación con la industria de la producción que busca deslumbrar y conmover a los espectadores.
\end{abstract}

Palabras Clave: Espectáculo | Guerra | Representación | Violencia | Imagen

\section{Dunkerque}

\section{Abstract}

The author interprets the discomfort and anger that she felt when she saw the chronicle of the operation Dynamo, Dunkirk, from the fright generated through the music, the insistent plans about the wounded and the dead. An insult to these dead heroes. This type of film can have a pedagogical character, but it is more about enjoying an awful spectacle. The spectator witnesses a history of the past but leaves it in a passive position.

The author also analyzes the degree of tolerance: there is acceptable violence and another that is not. It also distinguishes the productions that are directed to the destructive impulses of those that deal with releasing the spectator. In the case of this film, it is only about the inhumanity of blind destruction. Finally, he reflects on the relationship between cinema and art but also has a relationship with the production industry that seeks to dazzle and move viewers.

Key Words: Show | War | Representation | Violence | Image

Este título remite a Dunkerque, un documental ficcionado, de Christopher Nolan, gran crónica histórica de la operación Dynamo, la evacuación hasta las costas inglesas de 330.000 aliados en mayo de 1940.

Ficción porque los personajes son actores que reemplazan a los soldados reales, y, sin embargo, la película cuenta hechos históricos que existieron realmente.

Como espectadora, sentí cierto malestar que intentaré desplegar. Un malestar que sentí al tomar consciencia de la voluntad de manipular al espectador con la música, los planos insistentes sobre los heridos, los muertos; todo está ahí para espantar.

Einstein ${ }^{1}$ formula la pregunta: " $¿$ Hay alguna manera de liberar a la bumanidad de la amenaza de la guerra?”.

Su hipótesis sería que la fuerza de una institución que domina las naciones podría regular los odios de los hombres y, sobre todo, el apetito de poder de ciertas personas para quienes la guerra es la ocasión de sacar ventajas y así extender el campo de su poder personal.

Freud responde: 
La liga de las naciones, capaz de representar una prevención contra la guerra se vuelve impotente si no se sostiene también en el plano de las ideas. Freud construye así su teoría de la pulsión de muerte: "La pulsión de muerte se convierte en pulsión de destrucción...”.

El ser viviente preserva -por así decirlo- su propia vida destruyendo la del prójimo. Agrega que todo aquello que promueve el desarrollo cultural actúa a la vez contra la guerra. Freud concluye su respuesta a Einstein diciéndole que espera que sus palabras no lo hayan decepcionado mucho. Es verdad que no son muy optimistas...

¿Por qué una película de guerra? Para satisfacer nuestra pulsión escópica, nuestro voyeurismo, el ojo ya no como fuente de visión sino como fuente de libido.

La imagen que brilla atrae el ojo como un punto desde donde sale la luz, el objeto ágalma es causa de deseo para quien cayó en su trampa.

Entonces, ¿por qué este malestar? Engañada por las magníficas imágenes de la playa en la que esperan centenas de millares de hombres que serán diezmados muy rápidamente por las bombas del enemigo.

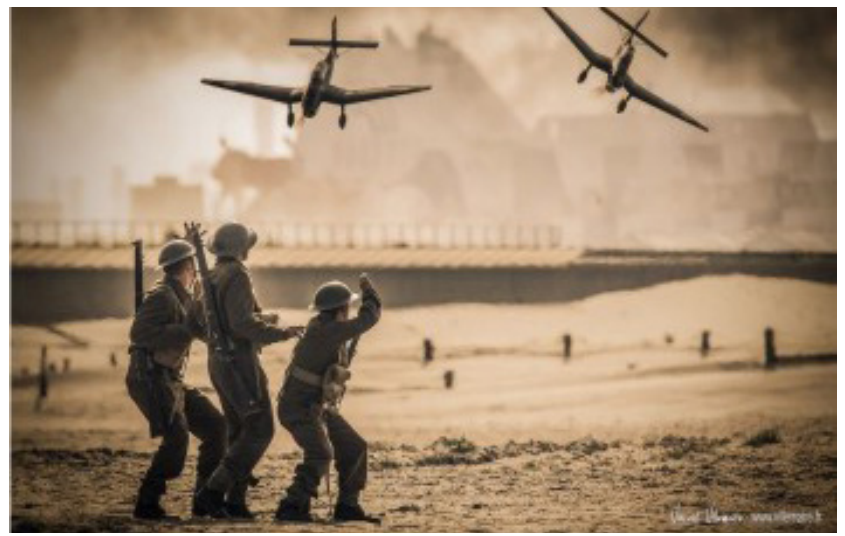

El sonido es ensordecedor, desgarrador. Las balas estallan, hay suspenso. Un travelling hacia delante sobre los soldados mientras corren de espaldas y que, luego, se desploman sobre los adoquines. Uno solo se queda parado, la cámara reencuadra sobre él, escala un muro para esconderse, las balas se acercan, su fusil está atascado, lo destrabamos con él en lo alto de la colina.

Ver esta inmensa playa y el magnífico grafismo de las tropas repartidas en guarniciones para embarcar en barcos que no llegan.

Este tipo de película puede tener un carácter pedagógico al mostrar el horror de la guerra y los errores cometidos por los jefes de los Estados Mayores de las Armadas, compensados por el sostén y la solidaridad de los civiles.

Sin embargo, a la salida de la proyección, estaba enojada. Enojada por haber mirado la película cómodamente, instalada en mi asiento junto con los otros espectadores delante de una gran pantalla, estar en el corazón de esa masacre e incluso, disfrutando. Entonces, ¿por qué? ¿Quizás el director al mostrar este hecho tan real me hizo decir que su película era un insulto a estos héroes muertos sin música de Zimmer ni suspenso, sino todo lo contrario, en pleno terror y sufrimiento? Aquí, me pregunto por su deseo.

La imagen muestra, no sugiere, al menos que haya una imagen que falta. En la película Dunkerque, se trata simplemente de gozar de un espectáculo espantoso. Un espectáculo que utiliza la técnica del espanto (en cámara lenta, con música particular, con efectos especiales) que lleva a desviar la mirada puesto que los artificios hemoglobinados, las explosiones, las heridas, las eventraciones provocan náuseas.

Si la víctima sirve como pretexto para una escalada hacia lo insoportable, fuerza la cuestión de la moral, aunque la película de guerra enmarca la narración conociendo ya las causas y las consecuencias.

Cito a Marc Olivier Padis "la imagen siempre representa algo que no está, solo puede hacer olvidar el vacio negándose a símisma. En eso consiste la mentira del simulacro; se hace pasar como evidente, presente, ya realizada".

Pero ¿cómo mostrar el sufrimiento sin ceder a la complacencia espectacular por el mal? La confrontación de los cineastas respecto a la cuestión de la violencia muestra justamente una capacidad a no reducir la imagen a las malas imágenes, la imagen puede ayudar a salir de la imposibilidad de representar el sufrimiento porque sigue siendo el lugar de la encarnación de Belzec ${ }^{2}$ de Guillaume Moscovitz.

Dunkerque no es Apocalypse Now, película marcada por el sello del gigantismo y de la locura.

De hecho, no hay lugar para comparar, pero las imágenes casi hipnóticas generan un efecto de verdad. En Dunkerque, está lo falso, la mentira, evidentemente, la mentira por omisión porque la dirección omite el sacrificio de decenas de millares de soldados franceses para hacer frente a los alemanes y los 1800 soldados de fuerzas reales hindúes enviados directamente de Bombay para colaborar con las tropas británicas.

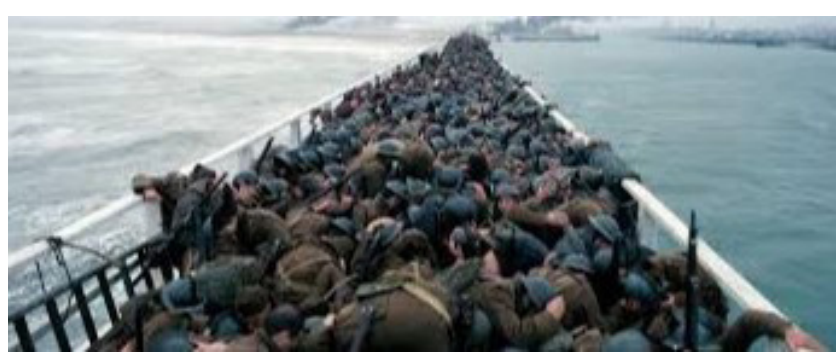


Dunkerque no es una película de propaganda, es una película entretenida de información. Sus imágenes son violentas también porque nuestra posibilidad para ver es limitada, pero no para actuar; somos testigos, imposibilitados porque es una historia del pasado. En esta posición pasiva, me sentí cómplice.

La representación de la violencia en el cine es un tema discutido reiteradamente. Carole Desbarat, directora de estudios en la Fémis, ${ }^{3}$ explica que el tema de la representación de la violencia en el cine es especialmente interesante si no se la considera con prejuicios. Como, efectivamente, el cine es un arte, no existe el imperativo universal que permita separar de manera categórica el grano del trigo, lo que hay que mostrar de lo que hay que prohibir hacer visible, una violencia aceptable de otra que no lo es. La frontera fluctúa de un director a otro, de una película a otra y de una época a otra, todos sabemos que el umbral de tolerancia de lo que podemos aceptar ver y oír en el cine varía incluso respecto a nosotros mismos a lo largo de nuestra vida.

¿Eso significa que debemos prohibirnos hacer un juicio sobre estos temas? Ciertamente no, y mucho más porque la representación de la violencia es omnipresente $\mathrm{y}$ toca todos los géneros de cine desde la ficción hasta el documental.

Muy por el contrario, es apasionante preguntarse sobre la manera en que la violencia fue puesta en escena por un director.

Para volver a la película, diré que no me parece ética o moral porque no filma en nombre de los más vulnerables para salvar su dignidad. Filma para el espectáculo brutal y violento, cuyo objetivo es espantarnos. Es el arte de manipular sutilmente al espectador, atrapado porque es una realidad. ¡No es cine! Serge Tisseron afirma que la imagen nos lleva y nos contiene por el deseo que tenemos de entrar, pero al mismo tiempo nos invita a hablar de ella y así poder separarnos. La imagen bajo la forma de dibujo, pintura, fotografía y luego cine, nos acompañó siempre.

Toda imagen crea la ilusión de contener en la realidad algo de lo que representa. Por más que sepa que la foto de una amiga solo es un pedazo de papel, si alguien lo daña, no puedo evitar pensar que es una ofensa hacia mi amiga; estamos en esa posición de creer que la imagen contiene efectivamente algo que de lo que representa.

Sentir esa ofensa está ligado a la realidad de esos soldados jóvenes, vivos, combatientes, valientes, heroicos representados por extras que, una vez que el rodaje termina, van a levantarse, lavar su falsa sangre e ir a tomar una copa entre ellos (lo verdadero borrado por lo falso).
Además, como dice Jean Louis Comolli, la competencia, la puja, la influencia reemplazó "la escuela al menos [l'école du moins]"; cuando todavía nos queda por ver quienes hacen honor a los Hawks, Fuller, etc...

La parte por el todo da cierto sentido de responsabilidad, el respeto del lugar del espectador y de su trabajo; la cuestión aquí es distinguir dentro de las producciones aquellas que se dirigen a las pulsiones destructivas y aquellas que se ocupan de liberar al espectador de una tal presión.

A partir de una investigación sobre la manera con la que los niños manejan los efectos de las imágenes violentas sobre sí mismos, Tisseron afirma "los niños a quienes se les muestran imágenes violentas tienen muchos más gestos y mimicas coherentes con el discurso, esto demuestra que las imágenes violentas no desestructuran la capacidad de pensamiento pero ponen en juego procesos de asimilación que pasan por la sensorio-motricidad".

Los padres y educadores deben permitir a los niños reconectar con las emociones que vivieron a través del juego, representándolas ya sea por el juego o por la palabra.

Además, en su estudio sobre la influencia de las imágenes televisivas, Tisseron afirma que las imágenes violentas llevan a los espectadores a renunciar a conductas moderadoras o pacificadoras que su educación les hizo adoptar. Estos niños no son más violentos, pero inhiben conductas de entreayuda [entraide] y de cooperación en las relaciones sociales, aunque ciertos juegos apelan a la entreayuda y a la solidaridad y otros no. Y, por otro lado, cada uno puede elegir jugar con un modo agresivo o cooperativo.

Respecto a Guillaume Moscovitz y su película Bel$z e c$, nos propone no estar sobrecargado de goce, pero sí activos en un saber que él nos transmite.

Dunkerque muestra una y otra vez los muertos, los heridos, las bombas. Nolan tiene los medios para denunciar este error político buscado o no por Churchill.

Muestra también la solidaridad de los ciudadanos que vienen uno tras otro con sus pequeños barcos a buscar y rescatar del agua a los soldados ahogados, extenuados, traumatizados.

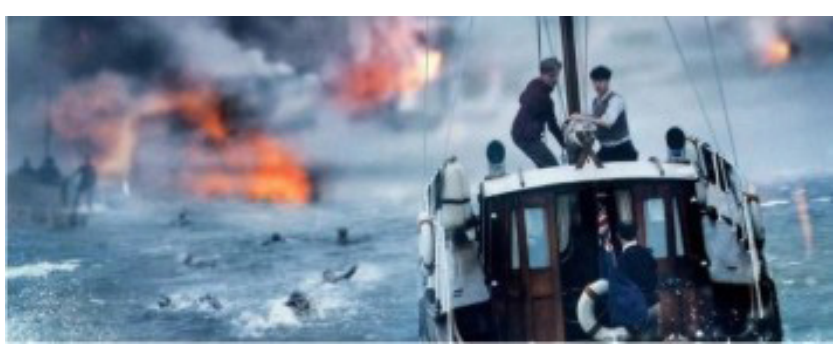


Hay violencia producida por imágenes que privan al espectador de su sentido crítico, de su facultad de ponerlas en perspectiva a partir de una reflexión razonada, a favor de una fascinación por la imagen que busca y provoca una sujeción [assujettissement] del espectador. Las escenas más íntimas ficcionadas en lugares singulares entre los civiles y los militares a veces son poco creíbles como este joven inglés que muere después de haberse caído de su barco.

Por este motivo, Nolan nos transmite la inhumanidad de la destrucción ciega, opuesta a la humanidad del cuidado y del rescate uno tras otro de los civiles.

Para terminar aquí con esta reflexión, una de las razones de mi malestar como espectadora, sería que la pantalla (una distancia entre la pantalla y el espectador) ya no funciona como pantalla. La pantalla es la interfase que refleja una realidad objetiva en una visión subjetiva. Las imágenes mienten ya que son falsas. Mirar a distancia, bajo la protección de una pantalla, la violencia que nos habita permite, ciertamente, evitar que se apodere de nosotros.

Para detener este efecto perverso, está la palabra, la palabra entre nosotros y a la salida de la función donde se suponía que ya no debía sufrir.

Ver la película con otros es importante. El público y lo social. Mis nietos adolescentes apreciaron esta película de otra manera y me aportaron un pensamiento crítico y una distancia.

Pienso que el lugar del espectador debe ser respetado y no paralizado, como ya dije, por la recepción de un programa imperativo que no provoca más que miedo. La palabra acompañada por la imagen construye una responsabilidad. La imagen puede aunar la palabra y la escritura como en la película Belzec.

La violencia es tonta, la guerra ciertamente lo es, la representación de esta última es tonta puesto que no es un juego.

La fascinación por la muerte es evidente en Dunkerque, a pesar de estar compensada por la salvación hacia la vida.

Para terminar, les propongo otra historia que puede ser comparada con Dunkerque. Se trata de una reflexión de Jean-Luc Dardenne que habla de su cine y del de su hermano como un lugar al igual que el libro de la escritora Elena Rjevskaïa. Notas de la intérprete de guerra del Estado Mayor de la Armada Roja [Carnets de l'interprète de guerre de l'état-major de l'Ar- mée]; Armada Roja que ella acompañó hasta el frente en Moscú y Berlín durante el invierno de 1941 y 1942. En el otoño, escribe: "Poco antes de nuestra partida de Stendal (pequeña ciudad del oeste de Berlín), me encontraba en una plaza. Por los caminos invadidos por el pasto, pasaba una pareja de enamorados, un arroyo y un pequeño puente que lo atravesaba,...”.

La narradora fija los leves burbujeos del agua, se evade, sale de sí misma, de su vida y del centro de la guerra. J-L. Dardenne asocia esta mirada a la del espectador del arte cinematográfico, las imágenes de muerte, de crueldad, no permiten que el espectador pueda evadirse.

Tratamos, dice, de encontrar un lugar poco propicio para la cámara, para el espectador, en donde falta algo, algo queda escondido, escapa y resiste a la toma de su mirada.

Y es, precisamente, lo que no vi en Dunkerque. Esas son las palabras de Luc Dardenne. De ahí el malestar, con la impresión de haber compartido el odio y la violencia de los Verdugos.

Las películas más violentas de Hawks, Kubrik, Tarantino, entre otros, representan a veces la violencia de la muerte en una fuerza, una mirada que la sublima, la estiliza, la espectaculariza, la pone a distancia por el juego, el marco, la ironía y, también, por el cuidado respecto al sufrimiento humano.

Samuel Füller decía que no habría que mostrar películas de guerra en una sala de cine, salvo tirando balazos (de fogueo) sobre los espectadores. Listo, ya se hace gracias a las innovaciones tecnológicas en las salas de cine Pathét equipadas con tecnología 4DX, con respaldos que vibran, asientos que se mueven en todos los sentidos y en cada choque que aparece en la pantalla, un soplador para las ráfagas de viento, vaporizadores para lanzar el agua de lluvia o salpicaduras, etc... Gadget para los espectadores afectados por la emoción y con escalofríos.

El cine, lamentablemente, no solo pertenece al arte sino también a la industria de la producción, siempre en un contexto cada vez más competitivo, busca deslumbrar y conmover cada vez más a los espectadores a través de puestas en escena posibles por una dirección científica. La ficción ya no es solo una distracción. ¿El espectador toma la distancia suficiente, esa distancia necesaria para extraerse de lo real? ¿Qué nuevas consecuencias tendrá sobre la consciencia y el comportamiento del hombre de mañana? 


\section{Traducción: Noelia Luzar}

1 Sigmund FREUD, 1933. “¿Por qué la guerra?”

2 Guillaume Moscovitz, Belzec, salió en DVD en el 2005.

3 N. de la T.: Fondation Européenne des métiers de l'image et du son [Fundación europea de oficios de la imagen y del sonido].

$4 \quad$ N. de la T.: Empresa francesa dedicada a la industria del cine y discos. 